\title{
EVALUATION OF ANTHOCYANINS AND OTHER PHENOLIC COMPOUNDS EXTRACTION FROM BLUEBERRY PROCESSING WASTE WITH ACIDIFIED WATER
}

\author{
IVANOR ZARDO* \\ MARCELO BRANDO** \\ LIGIA DAMASCENO FERREIRA MARCZAK ${ }^{\text {**t }}$ \\ CACIANO PELAYO ZAPATA NOREÑA ${ }^{* *+*}$
}

\begin{abstract}
Anthocyanins are natural pigments and they are responsible for the blue-to-red coloration of flowers, fruits and leaves. These phenolic compounds are also known to be beneficial to human health. Due to their instability under some factors like temperature, light and $\mathrm{pH}$ conditions, their applications in the food industry need further study. The aim of this study was to evaluate and improve methods for the extraction of anthocyanins and other phenolic compounds from blueberry pomace generated by the juice production process, getting an extract free of organic solvent. The extractions were realized with acidified distilled water ( $1 \%$ citric acid) as a solvent, varying the extraction time and temperature. Maximum yields of anthocyanins were obtained at $80{ }^{\circ} \mathrm{C}$ for 5 minutes, resulting in a total of $1,944.07 \pm 46.7 \mathrm{mg}$ of monomeric anthocyanins (cyanidin3-glucoside) per $100 \mathrm{~g}$ of dry pomace. The phenolic compounds showed a good correlation with antioxidant activity, and higher yields were obtained at high temperatures and for longer extraction times.
\end{abstract}

KEY-WORDS: ANTHOCYANINS; ANTIOXIDANT ACTIVITY; BLUEBERRIES; EXTRACTION; POMACE.

*Ph.D student in the area of heat and mass transfer, Chemical Engineering Departament, Universidade Federal do Rio Grande do Sul (UFRGS), Porto Alegre, RS (e-mail: ivanorzardo@gmail.com).

${ }^{* *}$ Graduate student in the area of heat and mass transfer, Chemical Engineering Departament, Universidade Federal do Rio Grande do Sul (UFRGS), Porto Alegre, RS (e-mail: marcelo.brando@rocketmail.com).

*** Professor, Chemical Engineering Departament, UFRGS, Porto Alegre, RS (e-mail: ligia@eng.ufrgs.br).

**** Professor, Institute of Food Science and Technology, UFRGS, Porto Alegre, RS (e-mail: czapatan@ufrgs. br). 


\section{INTRODUCTION}

Blueberry (Vaccinium corymbosum L.) is a fruit belonging to the family Ericaceae; it is native to North America and several regions of Europe and is primarily cultivated in these areas (Prodorutti e Pertot, 2007). Blueberry cultivation in Brazil is quite recent and can be done just in some regions due to the requirement for suitable climatic conditions for the development of the crop (e.g., the accumulation of 500 hours of chilling below $7.2^{\circ} \mathrm{C}$ ) (Herter e Wrege, 2007).

Of all the fresh fruits studied to date, the blueberry is one of the richest in antioxidants, being the anthocyanins the primary antioxidants components. Anthocyanins are natural pigments that belong to the group of compounds known as flavonoids. The various phenolic structures of anthocyanins are responsible for most of the blue and purple colors and all shades of red found in flowers, fruits, some leaves, stems and roots of plants (Bridle e Timberlake, 1997; CastañedaOvando et al., 2009).

Due to their great antioxidant potential and proven beneficial effects on human health, anthocyanins have attracted increasing interest in the food, pharmaceutical and cosmetic industries (Pazmiño-Durán et al., 2001; Castañeda-Ovando et al., 2009).

Fifteen anthocyanins have been characterized in highbush blueberries. These compounds are combinations of anthocyanidins (cyanidin, delphinidin, malvidin, peonidin and petunidin) with sugars (galactose, glucose and arabinose) (Tian et al., 2005).

The anthocyanins show antioxidant activity both in vitro and in vivo, protecting cells from oxidative stress and induced inflammation (Youdim et al., 2000). In studies of rats fed diets experimentally supplemented with blueberries, it has been shown that blueberry has the ability to slow and even reverse cognitive and motor deficits in aging induced by irradiation, with improvements in learning (Shukitt-Hale et al., 2007), increased neuronal development and survival of grafts of transplanted neural tissue (Willis et al., 2008). Blueberry produces satiety and thus serves as a modulator of weight (Molan, Lila e Mawson, 2008).

Moreover, according to Castrejón et al. (2008), diets with blueberry can demonstrate the ability to treat various gastrointestinal problems, reduce bad cholesterol, improve circulation, and prevent chronic diseases, e.g., cardiovascular disease and cancer.

The artificial synthesis of anthocyanins is still difficult and expensive. Accordingly, these compounds are obtained by extraction from plant species and especially from fruits, whose anthocyanin content is relatively high. For this reason, efforts are underway to expand the possibilities of obtaining anthocyanins on a large scale from natural sources in a sustainable manner to enable the development of their applications, with great benefits for society (Favaro, 2008).

In Brazil, the consumption of fresh blueberry fruit is still low. Most of the fresh product is processed to obtain juice and derivatives that are consumed in the form of beverages, syrups and other food products. Inevitably, this process generates waste products such as stems, seeds and peels, termed pomace, which are rich in polyphenols and anthocyanins and are a potential source of nutraceutical compounds and natural dyes (Lee e Wrolstad, 2004).

Pressed juice yield ranged from 74 to $83 \%(\mathrm{w} / \mathrm{w})$, but only 13 to $23 \%$ of the anthocyanins and 36 to $39 \%$ of the polyphenolics were recovered in the juice. A substantial amount of anthocyanins and polyphenolics (> $42 \%$ and $>15 \%$, respectively of the starting material) were present in the presscakes (Lee, Durst e Wrolstad, 2002).

Anthocyanins are very sensitive and can be destroyed by a variety of agents, including light, heat, $\mathrm{pH}$, and enzymes (Winefield et al., 2009).

The aim of this study was to analyze the performance of a candidate extraction procedure used to obtain anthocyanins from blueberry pomace generated by juice processing. Extraction was performed under different conditions (temperature, time) with the aim of maximizing yield and ensuring the durability of the anthocyanins recovered by solvent extraction. The anthocyanin extract was also analyzed to evaluate its content of total phenolics and its antioxidant activity. 


\section{MATERIALS AND METHODS}

\subsection{JUICE EXTRACTION AND POMACE OBTAINING}

Frozen blueberries were purchased from Italbraz Ltda, a company in Vacaria city in the state of Rio Grande do Sul. The blueberries were stored in $1 \mathrm{~kg}$ polyethylene bags and kept at $18{ }^{\circ} \mathrm{C}$ prior to juice extraction. To extract the juice and obtain pomace, the blueberries were thawed at room temperature (approximately $25{ }^{\circ} \mathrm{C}$ ) and subjected to a bleaching process. This process serves to inactivate the polyphenoloxidase enzymes (PPOs) that degrade anthocyanins. The bleaching was performed in an autoclave (Phoenix Luferco, model AV, Brasil) at $100{ }^{\circ} \mathrm{C}$ for 3 minutes, followed by cooling in cold water (Rossi et al., 2003). The blueberries were then manually mixed and milled in an Ultra Mixer (Britain, model XB986B, Brasil) until the product became homogeneous and large pieces of fruit were not observed. A small portion of the homogeneous mass was taken for further analysis. The remaining homogenate was manually pressed onto nylon fabric to separate the liquid portion (juice) from the solid part (pomace). The pomace was then frozen at $18^{\circ} \mathrm{C}$ prior to further use.

\subsection{DETERMINATION OF PROPERTIES OF FRUIT AND POMACE}

The physico-chemical properties of the analyzed blueberries were determined. The properties analyzed were the content of total soluble solids ( $\left.{ }^{\circ} \mathrm{Brix}\right)$, the $\mathrm{pH}$ and the total acidity. The content of soluble solids was determined using an analog benchtop refractometer, the $\mathrm{pH}$ was determined with a pH meter (Tecnal, model TEC-3 MP, Brazil) (AOAC method 981.12 (Aoac, 2000)), and the titratable acidity was determined with a volumetric method (AOAC method 942.15 (Aoac, 2002)), with the results expressed as the percentage of citric acid.

The moisture content of the pomace was determined gravimetrically according to AOAC method 934.06 (Aoac, 2000).

\subsection{OBTAINING ANTHOCYANIN EXTRACT FROM BLUEBERRY POMACE}

Conventional extraction of anthocyanins is usually performed with organic solvents, such as methanol, ethanol and acetone. However, an extract free of organic solvents was sought in this study because the extract is going to be used in foods. Accordingly, water was used as the basis for the solvent.

The extraction of anthocyanins was performed in batch mode with water in the presence of $1 \% \mathrm{w} / \mathrm{v}$ citric acid as solvent (Lee e Wrolstad, 2004). The extraction apparatus was a jacketed cell wrapped in aluminum foil to maintain the solution at a constant temperature and protect the solution from light during the extraction. To control the extraction temperature, a thermostatic bath (Lauda, model T TYP, Germany) was used. Constant stirring with a magnetic stirrer was used during the extraction.

The temperature $\left(60\right.$ and $\left.80^{\circ} \mathrm{C}\right)$ and time $(5,15$ and 45 minutes) for the extraction process were used in all possible combinations as experimental treatments, with a total of 6 treatments. Each batch used $4 \mathrm{~g}$ of wet pomace and $60 \mathrm{~mL}$ of extraction solution, the best ratio for this study (1:15) as determined by preliminary experiments.

To compare and analyze the effectiveness of each test extraction, an exhaustive extraction was performed to obtain an overall quantification of the compounds in the blueberry pomace. In this procedure, successive extractions were performed with methanol until no significant staining of the extract was noticed. The procedure was adapted from Larrauri, Rupérez e Saura-Calixto (1997).

After the completion of the extraction, the solution was vacuum filtered, the solid portion was 
discarded and the aqueous extract of anthocyanin was packed in amber glass bottles and stored in a refrigerator $\left(5^{\circ} \mathrm{C}\right)$ prior to further analysis.

All extractions were performed in triplicate.

\subsection{QUANTIFICATION OF TOTAL MONOMERIC ANTHOCYANINS BY SPECTROPHOTOMETRY}

The $\mathrm{pH}$ differential method described by Lee, Durst e Wrolstad (2005) was used. This method is based on the structural changes occurring in the anthocyanins in a $\mathrm{pH}$ range between 1.0 and 4.5. As the compounds are colored at $\mathrm{pH} 1.0$ and colorless at $\mathrm{pH} 4.5$, results can be obtained by spectroscopic observation. The sample is diluted in buffered solutions of $\mathrm{pH} 1.0$ and 4.5 with a predetermined dilution factor, and absorbance measurements are then made at specified wavelengths.

The $\mathrm{pH} 1.0$ buffer solution was prepared with potassium chloride and the $\mathrm{pH} 4.5$ buffer with sodium acetate. Distilled water was used to prepare both solutions. The dilution factor of the sample was determined to maintain the absorbance of the sample below a value of one.

Aspectrophotometer (pro-analysis, model UV 1600, Brazil) was used to read the absorbance. The absorbance was measured at 518 and $700 \mathrm{~nm}$; the wavelength that showed the maximum values of absorbance, $518 \mathrm{~nm}$, had been determined in a previous experiment. The difference between the absorbance values at both $\mathrm{pHs}$ analyzed, measured at the peak wavelength, is proportional to the concentration of anthocyanins (Giusti e Wrolstad, 2001; Wrolstad, Durst e Lee, 2005). The absorbance was determined according to Equation 1.

where is the absorbance at the wavelength of maximum detection of anthocyanins and is the absorbance at a wavelength of $700 \mathrm{~nm}$. The sample has no color absorbance at $700 \mathrm{~nm}$, and the measurement is performed only to correct errors related to the presence of turbidity or sediment in the sample.

The anthocyanin content in the sample was determined using Equation 2 and expressed in $\mathrm{mg} / \mathrm{L}$ of anthocyanin cyanidin-3-glucoside.

where is the absorbance calculated using Equation 1, $\left(449.2 \mathrm{~g} \mathrm{~mol}^{-1}\right)$ is the molar mass of cyanidin-3-glucoside, $\left(26,900 \mathrm{~L} . \mathrm{mol}^{-1} \cdot \mathrm{cm}^{-1}\right)$ is the molar extinction coefficient of anthocyanin, is the dilution factor of the sample, is the pathlength $(1 \mathrm{~cm})$ and is the factor conversion from $\mathrm{g}$ to $\mathrm{mg}$. Given the dilutions made in the sample and its moisture, the total anthocyanin content in mg per 100 $\mathrm{g}$ of sample on a dry weight basis can then be obtained.

The analyses were performed in triplicate for each treatment.

\subsection{PHENOLIC COMPOUNDS}

The determination of total phenolic compounds present in the samples of aqueous extract was made by the Folin-Ciocalteu method using gallic acid as the standard (Waterhouse, 2001). The Folin-Ciocalteu method is based on the chemical reduction of the oxides of tungsten and molybdenum, which have a blue color and are highly light-absorbent. The maximum absorbance of the mixture of these oxides occurs at a wavelength $(\lambda)$ of $765 \mathrm{~nm}$. The intensity of light absorption at this $\lambda$ is proportional to the concentration of phenolics (Waterhouse, 2001).

A total of $40 \mu \mathrm{L}$ of extract or standard gallic acid was pipetted into each test tube, to which $3.2 \mathrm{~mL}$ of distilled water and $200 \mu \mathrm{L}$ of Folin-Ciocalteu reagent were added. The mixture was stirred and protected from light for 5 minutes to allow the reaction to occur. After this period, $600 \mu \mathrm{L}$ of a saturated solution of sodium carbonate was added. The mixture was agitated in a vortex mixer 
(Phoenix Luferco model AP 56, Brazil) and left, protected from light, at room temperature for 1 hour. To read the absorbance, the samples were transferred to plastic buckets and the readings performed with a spectrophotometer (Pro Analysis, model UV 1600, Brazil) at a wavelength of $765 \mathrm{~nm}$. The results were expressed as mg of GAE (gallic acid equivalents) per $\mathrm{g}$ of pomace on a dry weight basis. For the preparation of the blank, the procedures were the same as those followed for sample preparation except that distilled water was substituted for the sample (Waterhouse, 2001).

A standard curve was created for the quantification of total phenolic compounds to specify the absorbance of solutions of various concentrations of gallic acid (50, 100, 300, 400 and 500 ppm) after the sample preparation procedure.

All experiments were performed in triplicate, and the obtained calibration curve coefficient was greater than 0.99 .

\subsection{TOTAL ANTIOXIDANT ACTIVITY (TAA)}

Numerous methods for the assessment of total antioxidant activity (TAA) have been proposed in the literature, but the suitability of a particular method will depend on the nature of the compounds present in each fruit. In this paper, spectrophotometric techniques involving ABTS and DPPH radicals were used to measure the antioxidant activity of the aqueous extract of blueberry pomace.

\subsubsection{Method Based on Capture of the DPPH Radical (2,2-Diphenyl-1-Picryhydrazyl)}

The DPPH assay is based on the capture of the radical 2,2-diphenyl-1-picrylhydrazyl by antioxidants present in the sample. The result of this reaction is a decrease in absorbance at a wavelength of $515 \mathrm{~nm}$ (Brand-Williams, Cuvelier e Berset, 1995).

The methodology used for the analysis and calculation of TAA with this technique was performed according to Brand-Williams, Cuvelier e Berset (1995), with several modifications.

For analysis, three dilutions of the aqueous extract of anthocyanins with distilled water were initially prepared in triplicate. Then, $0.1 \mathrm{~mL}$ aliquots of each extract dilution were transferred to assay tubes. A total of $3.9 \mathrm{~mL}$ of a $0.06 \mathrm{mmol} \mathrm{DPPH}$ solution was then added, and the mixture was homogenized with a vortex mixer (Phoenix Luferco model AP 56, Brazil). The $0.06 \mathrm{mmol}$ DPPH solution was prepared by dissolving the DPPH (2,2-diphenyl-1-picrylhydrazyl) in methyl alcohol on the day of analysis.

A control solution was prepared using a method parallel to that used for the samples but substituting distilled water for the sample. The mixtures were protected from light for $1 \mathrm{~h}$, and the absorbance was then measured with a spectrophotometer (Pro analysis, Model UV 1600, Brazil) at $515 \mathrm{~nm}$. Methyl alcohol was used as a blank to calibrate the spectrophotometer.

The final absorbance was interpolated into a Trolox standard curve, and the results were expressed as Trolox equivalent antioxidant activity (TEAC) (TEAC $\mu \mathrm{mol} / \mathrm{g}$ dry weight basis).

\subsubsection{Method for Capturing the ABTS Radical (2,2'-azino-bis (3-ethyl-benzothiazolinesulfoniclacid))}

This method is based on the energy of reaction required to form hydrogen donor compounds. In this method, the phenolic compounds of interest are converted into a colorless form of the ABTS radical (Campos e Lissi, 1997).

The methodology used for the TAA analysis and calculations with ABTS radical capture was based on Re et al. (1999) with several modifications.

The ABTS reagent (Sigma Aldrich, St. Louis, USA) was dissolved in distilled water to form a $7 \mathrm{mmol} / \mathrm{L}$ solution. The ABTS radical was produced 16 hours prior to use by reacting $7 \mathrm{mmol} / \mathrm{L}$ ABTS solution with $4.9 \mathrm{mmol}$ potassium persulfate in a 1:1 ratio solution. For the assay, the solution containing the ABTS radical was diluted with ethanol to obtain an absorbance of $0.7 \pm 0.05$ at $734 \mathrm{~nm}$. 
Three dilutions of the aqueous extract of anthocyanins were initially prepared with distilled water in triplicate. Aliquots of $30 \mathrm{~mL}$ of each dilution of the extract were transferred to assay tubes, $3 \mathrm{~mL}$ of the ABTS radical were added, and the mixture was homogenized in a vortex mixer (Phoenix Luferco, model AP 56, Brazil). The mixtures were protected from light for 20 minutes, and the absorbance was then measured with a spectrophotometer (Pro analysis, Model UV 1600, Brazil) at $734 \mathrm{~nm}$. Ethanol was used as a blank to calibrate the spectrophotometer.

The total antioxidant capacity of the sample was calculated relative to the activity of the synthetic antioxidant Trolox (Sigma Aldrich, St. Louis, USA), and the results were expressed as the Trolox equivalent antioxidant activity (TEAC) (TEAC $\mu \mathrm{mol} / \mathrm{g}$ pomace) (dry weight basis).

\subsection{STATISTICAL ANALYSIS}

An analysis of variance (ANOVA) was used to evaluate the results. Differences between treatments were evaluated with a Tukey test with a statistical significance level of 0.05 . The statistical analyses were performed with Statistical software for Windows (version 11, StatSoft $®$ ) (Statsoft, 2012)).

\section{RESULTS AND DISCUSSION}

The pomace obtained from blueberries processed to produce juice was found to have a soluble solid content of $12 \pm 0.1^{\circ} \mathrm{Brix}$, a pH of $3.05 \pm 0.01$ and a total acidity, expressed as the percentage of citric acid, of $0.433 \pm 0.006 \%$. The juice yield from processing blueberry was $83.4 \%$, leaving $16.6 \%$ by mass of waste. The moisture content of the presscake pomace was $67.77 \pm 0.46 \%$.

\subsection{EXTRACTION OF ANTHOCYANINS}

The extraction of anthocyanins was performed without using organic solvents. Only acidified water was used as the extracting solvent.

The degree of extraction of anthocyanins depends on a number of factors, including the ratio of the solvent volume to the mass of the sample, the type of solvent, the $\mathrm{pH}$, the type of acid (hydrochloric acid, citric acid, tartaric acid, acetic acid), the particle size, and the time and temperature of extraction (Cacace e Mazza, 2003; Lee e Wrolstad, 2004).

According to Xavier et al. (2008), the optimum conditions for the extraction of anthocyanins from red cabbage occur at $\mathrm{pH}$ 2.3. The most commonly used acidulant in extraction solutions is hydrochloric acid $(\mathrm{HCl})$. However, citric acid was used in this study because $\mathrm{HCl}$ is harmful to human health. Citric acid has no detrimental effects and can act as a preservative during the processing and storage of the extract (Main, Clydesdale e Francis, 1978). Excess acidity in the medium (pH below 1) can result in the formation of anthocyanidins and other flavonoids through hydrolysis reactions, generating underestimates of the total amount of anthocyanins (Revilla, Ryan e Martín-Ortega, 1998). For this reason, a $1 \%$ solution of citric acid was used in this study.

Figure 1 shows the anthocyanin concentration in mg per $100 \mathrm{~g}$ pomace (dry weight basis) plotted versus the extraction time in minutes for the two temperatures used in the study (60 and 80 $\left.{ }^{\circ} \mathrm{C}\right)$. 


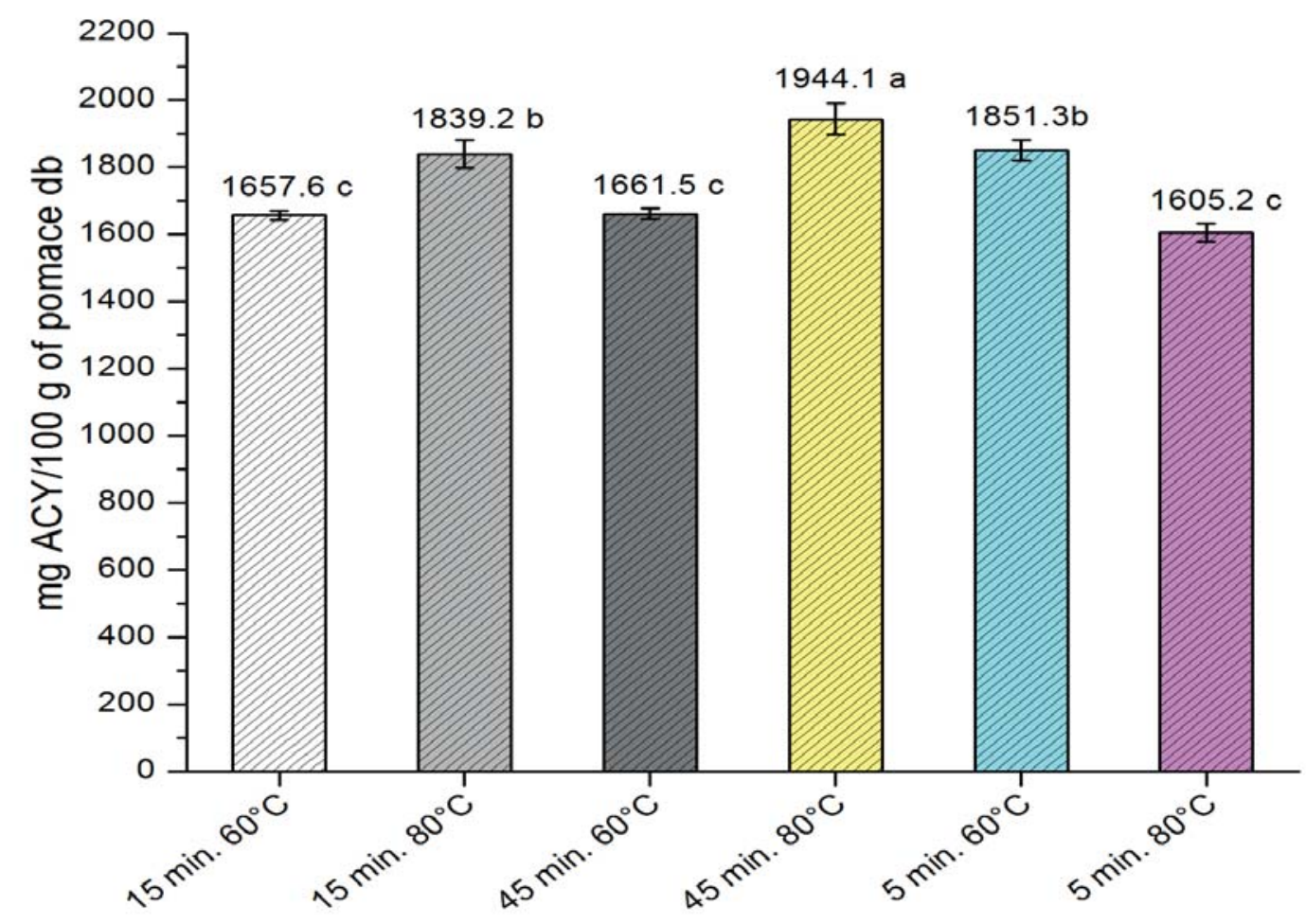

\section{FIGURE 1 - ANTHOCYANIN CONCENTRATION (MG OF CYANIDIN-3-GLUCOSIDE PER 100 G POMACE, DRY WEIGHT BASIS) AS A FUNCTION OF EXTRACTION TIME FOR DIFFERENT TEMPERATURES. BARS WITH THE SAME LETTER DO NOT DIFFER SIGNIFICANTLY (TUKEY TEST, 5\% PROBABILITY).}

The Figure 1 shows that the amount of anthocyanins extracted was greater for the shorter times at the higher temperature. However, a decrease in the concentration of anthocyanins in the extract was observed at $80^{\circ} \mathrm{C}$ for the long experimental periods. The highest value was obtained for the extraction conditions of $80^{\circ} \mathrm{C}$ and 5 minutes. Under these conditions, $1,944.07 \pm 46.7 \mathrm{mg}$ of monomeric anthocyanins (cyanidin-3-glucoside) were obtained per $100 \mathrm{~g}$ pomace dry weight basis. This result represents $81.41 \%$ of the total anthocyanin concentration $(2,387.9 \mathrm{mg} / 100 \mathrm{~g}$ pomace dry weight basis) resulting from the exhaustive extraction of blueberry pomace. Accordingly, the technique appears to be highly efficient.

Similar results were found for blueberry pomace by Lotfi et al. (2013) and by Su e Silva (2006) and for grape pomace by Valduga et al. (2008). Nicoué, Savard e Belkacemi (2007) obtained the best results for the extraction of total anthocyanins from whole blueberries with $5 \%$ formic acid in ethanol at $79^{\circ} \mathrm{C}$ for 2 hours, a total of $2,890 \mathrm{mg} / 100 \mathrm{~g}$ of fruit pomace (dry weight basis).

The rapid extraction of anthocyanins demonstrated in Figure 1, compared with the results obtained by other authors, e.g., 2 hours for the extraction of anthocyanins from blueberry (Nicoué, Savard e Belkacemi, 2007) and 3 hours for the extraction of anthocyanins from grape pomace (Lotfi et al., 2013) may be associated with the degree of disruption of the peel occurring during grinding by the mixer. This process may have exposed a greater area to extraction.

Figure 1 also shows that the concentration of anthocyanins decreases after a certain extraction time at the same temperature with the exception of the 5 and 15 minutes extraction times at $60^{\circ} \mathrm{C}$. This behavior may be due to anthocyanin degradation caused by prolonged exposure to high temperature: the hydrolysis of the glycoside bond and subsequent formation of chalcones 
causes a loss of color (Adams e Woodman, 1973). Lee e Wrolstad (2004) studied the extraction of anthocyanins from blueberry pulp at temperatures between 50 and $80^{\circ} \mathrm{C}$ with distilled water in the presence of $1 \%$ citric acid and $100 \mathrm{ppm} \mathrm{SO} \mathrm{S}_{2}$ with an extraction time of 1 hour. They found that the best performance occurred at $50^{\circ} \mathrm{C}$, whereas extraction at $80^{\circ} \mathrm{C}$ could have caused degradation of the anthocyanins due to the prolonged exposure at this high temperature.

A Tukey test showed that the average anthocyanin concentration under the optimal extraction conditions $\left(80^{\circ} \mathrm{C}\right.$ and 5 minutes) differed significantly $(p<0.05)$ from the values under the other conditions. The results for 60 and $80^{\circ} \mathrm{C}$ for 15 minutes did not differ significantly $(p>0.05)$. Likewise, the results for $60^{\circ} \mathrm{C}$ for 5 and 45 minutes and $80^{\circ} \mathrm{C}$ for 5 minutes did not differ significantly.

\subsection{TOTAL PHENOLICS}

The phenolics present in a sample are all compounds having an aromatic ring linked to one or more hydroxyl groups. This structure is termed a phenolic ring. The quantification of such compounds is an estimate of all the compounds belonging to the subclass of phenolic compounds (Pertuzatt, 2009).

Figure 2 shows the total phenolics extracted, expressed as $\mathrm{mg}$ of gallic acid per 100 $\mathrm{g}$ of pomace (dry weight basis) as a function of the temperatures and extraction times.

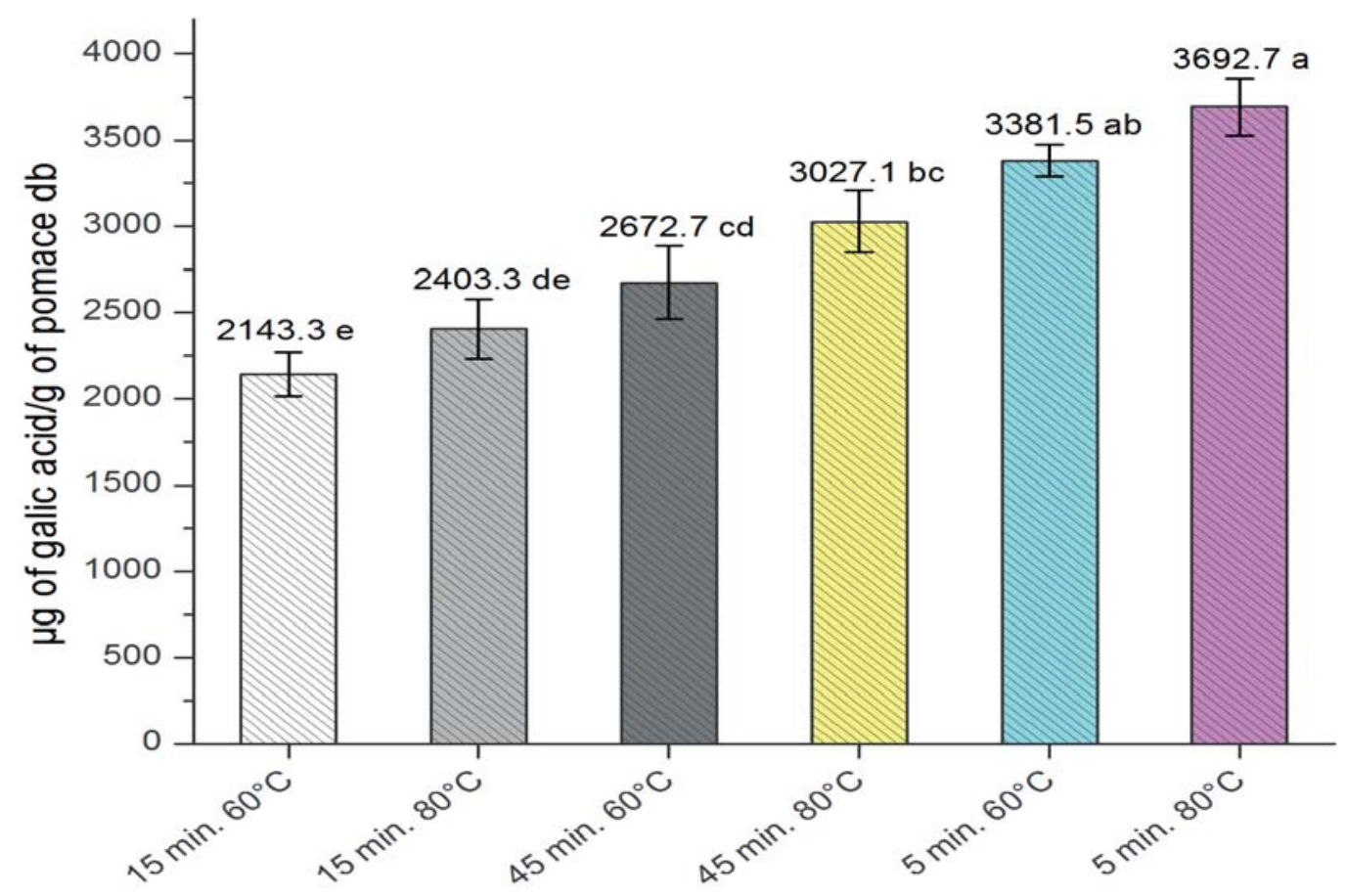

FIGURE 2 - CONCENTRATION OF TOTAL PHENOLICS IN MG OF GALLIC ACID PER $100 \mathrm{G}$ OF POMACE (DRY WEIGHT BASIS) VS. EXTRACTION TIMES AT DIFFERENT TEMPERATURES. BARS WITH THE SAME LETTER DO NOT DIFFER SIGNIFICANTLY (TUKEY TEST, 5\% PROBABILITY).

It can be seen that higher concentrations of total phenolics were obtained at the higher temperature $\left(80^{\circ} \mathrm{C}\right)$ for the same times. A Tukey test showed that the results obtained for the same extraction times at the two different temperatures $\left(60\right.$ and $\left.80^{\circ} \mathrm{C}\right)$ differed significantly $(p<0.05)$. No significant difference was observed between the extractions for 15 and 45 minutes at $80^{\circ} \mathrm{C}$. The 
maximum total phenolics extracted from blueberry pomace averaged $794.67 \pm 35.3 \mathrm{mg}$ of gallic acid per $100 \mathrm{~g}$ of extract. This value is equivalent to $3,698.46 \pm 164.36 \mathrm{mg}$ of gallic acid per $100 \mathrm{~g}$ of pomace on a dry weight basis, and it corresponded to a yield of $81.5 \%$ relative to the $4,533.45 \pm$ $293.86 \mathrm{mg}$ of gallic acid per $100 \mathrm{~g}$ of pomace on a dry weight basis obtained by exhaustive extraction.

Lee e Wrolstad (2004) extracted phenolic compounds from blueberry pomace with acidified water and $100 \mathrm{ppm} \mathrm{SO} \mathrm{S}_{2}$ at $80{ }^{\circ} \mathrm{C}$ for one hour. In their study, the maximum total phenolics in the extract had a value of $978.3 \mathrm{mg}$ of gallic acid per $100 \mathrm{~g}$ of the pomace extract. The sample mass ratio/volume of solvent was $1: 2 \mathrm{w} / \mathrm{v}$. Their study is the only previous investigation of the topic in the literature. The total yield of phenolics found in blueberry extract by Kalt, Mcdonald e Donner (2000) was twice as high at $60{ }^{\circ} \mathrm{C}$ than at $25^{\circ} \mathrm{C}$. This result showed that higher temperatures favor the extraction of phenolic compounds. Bucić-Kojić et al. (2011) studied the influence of the solvent (50$80 \%$ ethanol in water $(\mathrm{v} / \mathrm{v}))$ and temperature $\left(25-80^{\circ} \mathrm{C}\right)$ on the extraction of phenolic compounds from freeze-dried figs (Ficus carica L.). They concluded that the greatest ratios of alcohol to water and relatively high extraction temperatures positively influenced the extraction of phenolic compounds.

\subsection{ANTIOXIDANT ACTIVITY}

Figure 3 shows the values of antioxidant activity, expressed as TEAC $\mu \mathrm{mol} / \mathrm{g}$ of sample on a dry weight basis, resulting from two methods of analysis, DPPH (A) and ABTS (B).

As can be seen, the average value of antioxidant activity found in aqueous extracts of blueberry pomace was greater at the higher extraction temperature. The average values of antioxidant activity at $60^{\circ} \mathrm{C}$ at different times (5,15 and 45 minutes) analyzed by the DPPH method did not differ significantly $(p>0.05)$. The best results were found at a temperature of $80^{\circ} \mathrm{C}$ for 15 and 45 minutes. The average values for these two times did not differ significantly $(p>0.05)$. The values obtained with the ABTS method were higher but resembled the findings obtained with the DPPH method, namely, a higher antioxidant activity at the higher temperature of extraction $\left(80^{\circ} \mathrm{C}\right)$. The average values of antioxidant activity at 60 and $80^{\circ} \mathrm{C}$ analyzed by the ABTS method showed no significant difference between the extraction times of 15 and 45 minutes $(p>0.05)$.

Higher temperatures have the disadvantage of promoting the destruction of certain anthocyanins and phenolic compounds. However, such temperatures can also increase the bioavailability of compounds with antioxidant activity. Among the antioxidants present in fruits and vegetables, the most active and frequently encountered are phenolic compounds such as phenolic acids and flavonoids (Silva, Vendruscolo e Toralles, 2013).

The best extraction conditions, resulting in an extract with the highest average antioxidant activity, was at a temperature of $80^{\circ} \mathrm{C}$ for 15 and $45 \mathrm{~min}$ for both methods (DPPH and ABTS). The values obtained with the DPPH and ABTS methods were $275.99 \pm 4.67$ and $189.15 \pm 11.32 \mu \mathrm{mol}$ TEAC/g sample on a dry weight basis, respectively.

The values of antioxidant activity obtained by both methods were correlated with the total phenolic content and the results are presented in Table 1. The concentration of total phenolics and antioxidant activity were strongly correlated. This result indicates that phenolic compounds are primarily responsible for the antioxidant activity of the extract. 

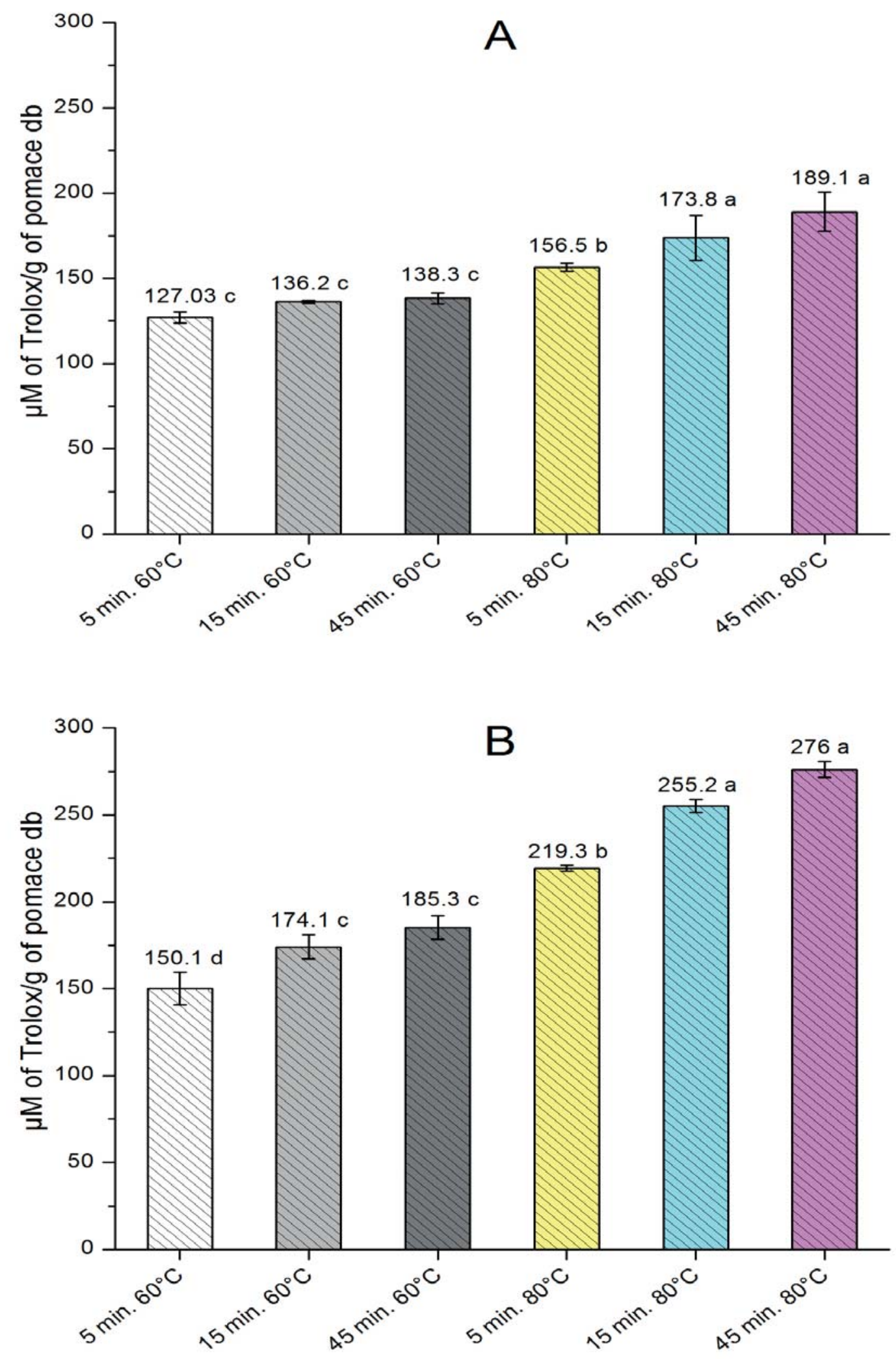

FIGURE 3 - ANTIOXIDANT ACTIVITY OF BLUEBERRY POMACE EXTRACT ANALYZED BY DPPH AND ABTS METHODS. BARS WITH THE SAME LETTER DO NOT DIFFER SIGNIFICANTLY (TUKEY TEST, 5\% PROBABILITY). 


\section{TABLE 1 - PEARSON CORRELATION COEFFICIENTS BETWEEN TOTAL PHENOLICS AND ANTIOXIDANT ACTIVITY (DPPH, ABTS) IN ANTHOCYANIN EXTRACT.}

\begin{tabular}{llll}
\cline { 2 - 4 } & Temperature & DPPH & ABTS \\
\hline \multirow{2}{*}{ Total Phenolics } & $60{ }^{\circ} \mathrm{C}$ & 0.937 & 0.977 \\
& $80^{\circ} \mathrm{C}$ & 0.999 & 0.993 \\
\hline
\end{tabular}

Dragović-Uzelac et al. (2010 evaluated the antioxidant capacity of different blueberry cultivars with the DPPH and ABTS methods and found that the values of antioxidant activity measured by the ABTS method (15.8 to $28.4 \mathrm{mmol}$ TEAC/100 $\mathrm{g}$ of fresh fruit) were higher than those measured by the DPPH method (5.6 to $7.6 \mathrm{mmol}$ TEAC/100 $\mathrm{g}$ of fresh fruit). The values of antioxidant activity measured by both methods showed a good correlation with the amount of phenolic compounds in the fruit.

The results of this study showed that the best conditions for the extraction of anthocyanins from blueberry pomace were an extraction temperature of $80{ }^{\circ} \mathrm{C}$ for 5 minutes. Longer extraction times resulted in a decrease in the concentration of anthocyanins as a result of thermal degradation, with possible formation of chalcones and consequent loss of color. Total phenolics and antioxidant activity were most efficiently extracted at a temperature of $80^{\circ} \mathrm{C}$ for 15 and 45 minutes. No significant difference was found between the average values obtained for these two extraction times.

\section{CONCLUSIONS}

Blueberry processing waste is high in anthocyanins and total phenolics and is a good potential source of natural colorants and nutraceutical compounds. This study found satisfactory results for the extraction of anthocyanins. The optimum extraction conditions were found to be 80 ${ }^{\circ} \mathrm{C}$ for 5 minutes. This result shows that high temperatures favor anthocyanin extraction and short extraction times serve to prevent thermal degradation.

The total phenolics and antioxidant activity of the extract showed a good correlation with the studied extraction conditions for both methods (DPPH and ABTS). The maximum yields were obtained at $80{ }^{\circ} \mathrm{C}$ for 15 and 45 minutes of extraction.

The results of this study are useful for increasing the recovery of anthocyanins and polyphenolics from extracts, reducing byproduct disposal and enhancing the utility of the blueberry fruit in addition to producing an extract free of organic solvents, a result of special interest to the food industry.

\section{RESUMO}

\section{AVALIAÇÃO DA EXTRAÇÃO DE ANTOCIANINAS E OUTROS COMPOSTOS FENÓLICOS DO RESÍDUO DO PROCESSAMENTO DO MIRTILO COM ÁGUA ACIDIFICADA}

Antocianinas são pigmentos naturais responsáveis pela coloração entre o vermelho e o azul de flores, frutas e folhas. Estes compostos fenólicos possuem elevado interesse por apresentarem diversos benefícios à saúde humana. Devido a sua instabilidade frente a algumas condições de temperatura, luminosidade e $\mathrm{pH}$, sua aplicação na indústria alimentícia demanda estudos mais aprofundados. O objetivo deste estudo foi avaliar e melhorar métodos de extração de antocianinas e outros compostos fenólicos do bagaço de mirtilo gerado pelo processo de produção de sucos, obtendo-se um extrato livre de solventes orgânicos. A extração foi realizada com água acidificada (1\% de ácido cítrico) como solvente, variando o tempo e a temperatura de extração. Os melhores 
rendimentos em antocianinas foram obtidos a $80^{\circ} \mathrm{C}$ por 5 minutos, resultando num total de $1.944,7$ $\pm 46,7 \mathrm{mg}$ de antocianinas monoméricas (cianidina-3-glucosídeo) por $100 \mathrm{~g}$ de bagaço em base seca. Os compostos fenólicos mostraram boa correlação com a atividade antioxidante, e maiores rendimentos foram obtidos em maiores temperaturas e por tempos de extração mais prolongados.

PALAVRAS-CHAVE: ANTOCIANINAS; ATIVIDADE ANTIOXIDANTE; MIRTILO; EXTRAÇÃO; BAGAÇO.

\section{REFERENCES}

1 ADAMS, J. B.; WOODMAN, J. S. Thermal degradation of anthocyanins with particular reference to the 3-glycosides of cyanidin. II. The anaerobic degradation of cyanidin-3-rutinoside at $100^{\circ} \mathrm{C}$ and pH 3.0 in the presence of sodium sulphite. Journal of the Science of Food and Agriculture, v. 24, n. 7, p. 763-768, 1973.

2 AOAC. Official Methods of Analysis of the Association of Official Analytical Chemists. Gaithersburg, Estados Unidos 2000. Unidos 2002.

Official Methods of Analysis of the Association of Official Analytical Chemists. Gaithersburg, Estados

4 BRAND-WILLIAMS, W.; CUVELIER, M. E.; BERSET, C. Use of a free radical method to evaluate antioxidant activity. LWT - Food Science and Technology, v. 28, n. 1, p. 25-30, 1995.

5 BRIDLE, P.; TIMBERLAKE, C. F. Anthocyanins as natural food colours: selected aspects. Food Chemistry, v. 58, n. 1-2, p. 103-109, 1997.

6 BUCIĆ-KOJIĆ, A. et al. Effect of Extraction Conditions on the Extractability of Phenolic Compounds from Lyophilised Fig Fruits (Ficus Carica L.). Polish Journal of Food and Nutrition Sciences, v. 61, n. 3, p. 195-199, 2011.

7 CACACE, J. E.; MAZZA, G. Optimization of Extraction of Anthocyanins from Black Currants with Aqueous Ethanol. Journal of Food Science, v. 68, n. 1, p. 240-248, 2003.

8 CAMPOS, A. M.; LISSI, E. A. Kinetics of the reaction between 2,2?-azinobis (3-ethylbenzothiazoline-6-sulfonic acid (ABTS) derived radical cations and phenols. International Journal of Chemical Kinetics, v. 29, n. 3, p. 219-224, 1997.

9 CASTAÑEDA-OVANDO, A. et al. Chemical studies of anthocyanins: A review Possible biological role of some anthocyanins in food. Food Chemistry, v. 113, n. 4, p. 859-871, 2009.

10 CASTREJÓN, A. D. R. et al. Phenolic profile and antioxidant activity of highbush blueberry (Vaccinium corymbosum L.) during fruit maturation and ripening. Food Chemistry, v. 109, n. 3, p. 564-572, 2008.

11 DRAGOVIĆ-UZELAC, V. et al. Evaluation of Phenolic Content and Antioxidant Capacity of Blueberry Cultivars (Vaccinium corymbosum L.) Grown in the Northwest Croatia. Food Technology and Biotechnology, v. 48, n. 2, p. 214-221, 2010.

12 FAVARO, M. M. A. Extração, estabilidade e quantificação de antocianinas de frutas típicas brasileiras para aplicação industrial como corantes. 2008. Universidade Estadual de Campinas, Campinas.

13 GIUSTI, M. M.; WROLSTAD, R. E. Characterization and Measurement of Anthocyanins by UV-Visible Spectroscopy. In: (Ed.): John Wiley \& Sons, Inc., 2001.

14 HERTER, F. G.; WREGE, M. S. Fatores Climáticos. Pelotas. Sistema de: 17-17 p. 2007.

15 KALT, W.; MCDONALD, J. E.; DONNER, H. Anthocyanins, Phenolics, and Antioxidant Capacity of Processed Lowbush Blueberry Products. Journal of Food Science, v. 65, n. 3, p. 390-393, 2000.

16 LARRAURI, J. A.; RUPÉREZ, P.; SAURA-CALIXTO, F. Effect of Drying Temperature on the Stability of Polyphenols and Antioxidant Activity of Red Grape Pomace Peels. Journal of Agricultural and Food Chemistry, v. 45, n. 4, p. 13901393, 1997.

17 LEE, J.; DURST, R. W.; WROLSTAD, R. E. Impact of Juice Processing on Blueberry Anthocyanins and Polyphenolics: Comparison of Two Pretreatments. Journal of Food Science, v. 67, n. 5, p. 1660-1667, 2002. 
19 LEE, J.; WROLSTAD, R. E. Extraction of anthocyanins and polyphenolics from blueberry processing waste. Journal of Food Science, v. 69, n. 7, p. 564-573, 2004. ISSN 1750-3841.

20 LOTFI, L. et al. Effects of sulfur water extraction on anthocyanins properties of tepals in flower of saffron (Crocus sativus L). Journal of Food Science and Technology, p. 1-9, 2013.

21 MAIN, J. H.; CLYDESDALE, F. M.; FRANCIS, F. J. SPRAY DRYING ANTHOCYANIN CONCENTRATES FOR USE AS FOOD COLORANTS. Journal of Food Science, v. 43, n. 6, p. 1693-1694, 1978.

22 MOLAN, A. L.; LILA, M. A.; MAWSON, J. Satiety in rats following blueberry extract consumption induced by appetitesuppressing mechanisms unrelated to in vitro or in vivo antioxidant capacity. Food Chemistry, v. 107, n. 3, p. 1039-1044, 2008. ISSN 0308-8146.

23 NICOUÉ, E. É.; SAVARD, S.; BELKACEMI, K. Anthocyanins in Wild Blueberries of Quebec. Extraction and Identification. Journal of Agricultural and Food Chemistry, v. 55, n. 14, p. 5626-5635, 2007.

24 PAZMIÑO-DURÁN, A. E. et al. Anthocyanins from Oxalis triangularis as potential food colorants. Food Chemistry, v. 75, n. 2, p. 211-216, 2001.

25 PERTUZATT, P. B. P. Compostos bioativos em diferentes cultivares de mirtilo (Vaccinium ashei Reade). 2009.

26 PRODORUTTI, D.; PERTOT, I. Highbush blueberry: cultivation, protection, breeding and biotechnology. The European journal of plant science and biotechnology, 2007.

$27 \mathrm{RE}, \mathrm{R}$. et al. Antioxidant activity applying an improved ABTS radical cation decolorization assay. Free radical biology and medicine, v. 26, n. 9, p. 1231-1237, 1999. ISSN 0891-5849.

28 REVILLA, E.; RYAN, J.-M.; MARTÍN-ORTEGA, G. Comparison of Several Procedures Used for the Extraction of Anthocyanins from Red Grapes. Journal of Agricultural and Food Chemistry, v. 46, n. 11, p. 4592-4597, 1998/11/01 1998. ISSN 0021-8561.

29 ROSSI, M. et al. Effect of fruit blanching on phenolics and radical scavenging activity of highbush blueberry juice. Food Research International, v. 36, n. 9-10, p. 999-1005, // 2003. ISSN 0963-9969.

30 SHUKITT-HALE, B. et al. Beneficial effects of fruit extracts on neuronal function and behavior in a rodent model of accelerated aging. Neurobiology of Aging, v. 28, n. 8, p. 1187-1194, 8// 2007. ISSN 0197-4580.

31 SILVA, R. S.; VENDRUSCOLO, J. L.; TORALLES, R. P. Avaliação da capacidade antioxidante em frutas produzidas na região sul do rs. Current Agricultural Science and Technology, v. 17, n. 3, 2013. ISSN 2317-2436.

32 STATSOFT. STATISTICA (data analisys software system) 2012.

33 SU, M.-S.; SILVA, J. L. Antioxidant activity, anthocyanins, and phenolics of rabbiteye blueberry ( Vaccinium ashei) byproducts as affected by fermentation. Food Chemistry, v. 97, n. 3, p. 447-451, 2006. ISSN 0308-8146.

34 TIAN, Q. et al. Screening for anthocyanins using high-performance liquid chromatography coupled to electrospray ionization tandem mass spectrometry with precursor-ion analysis, product-ion analysis, common-neutral-loss analysis, and selected reaction monitoring. Journal of Chromatography A, v. 1091, n. 1-2, p. 72-82, 2005.

35 VALDUGA, E. et al. Extração, secagem por atomização e microencapsulamento de antocianinas do bagaço da uva isabel (Vitis labrusca). a a, v. 1, n. 2, p. 1-1, 2008.

36 WATERHOUSE, A. L. Current Protocols in Food Analytical Chemistry. Hoboken, NJ, USA: John Wiley \& Sons, Inc., 2001. ISBN 0471142913.

37 WILLIS, L. M. et al. Dietary blueberry supplementation affects growth but not vascularization of neural transplants. J Cereb Blood Flow Metab, v. 28, n. 6, p. 1150-1164, 2008.

38 WINEFIELD, C. et al. Anthocyanins as Food Colorants. In: (Ed.): Springer New York, 2009. p.284-304.

39 WROLSTAD, R. E.; DURST, R. W.; LEE, J. Tracking color and pigment changes in anthocyanin products. Trends in Food Science \& Technology, v. 16, n. 9, p. 423-428, 2005.

40 XAVIER, M. F. et al. Extraction of red cabbage anthocyanins: optimization of the operation conditions of the column process. Brazilian Archives of Biology and Technology, v. 51, p. 143-152, 2008. ISSN 1516-8913.

41 YOUDIM, K. A. et al. Polyphenolics enhance red blood cell resistance to oxidative stress: in vitro and in vivo. Biochimica et Biophysica Acta (BBA) - General Subjects, v. 1523, n. 1, p. 117-122, 2000. 


\section{ACKNOWLEDGEMENTS}

The authors gratefully acknowledge the financial support from Fundação de Amparo à Pesquisa do Estado do Rio Grande do Sul (FAPERGS), Brazil and Coordenação de Aperfeiçoamento de Pessoal de Nível Superior (CAPES). 